\title{
Assumptions and implementation of the policy of Polish government in the field of the development of shipbuilding industry in Poland in the context of the situation on the shipyard market in the world
}

\begin{abstract}
In 2015, Polish government announced the reconstruction of the shipbuilding industry, involving among others the companies established after the collapse of the shipyard in Szczecin in this process consisting in the construction of big modern ships. The aim of the article is to present the assumptions and realization of the policy of Polish government in the scope of the development of shipbuilding industry in Poland after the year 2015. Particular attention was paid to government's decision aiming at the realization of shipbuilding industry development program in the context of the situation on global shipbuilding market. The attempts were undertaken to answer the following questions: What are the assumptions of the policy of Polish government in the context of the development of Polish shipbuilding industry after the year 2015?; What is the scope of realization of the assumptions of Polish governmental program addressed to the shipbuilding industry in the years 2016-2018? Is current policy of the government going to influence the establishment of a powerful center for the construction of ships within the premises of the former Szczecin shipyard? While aiming at finding the answers to research questions formulated in this way, the decision method was applied for the analysis of decisions made by the Council of Ministers concerning the implementation of the "Batory" program. The institutional and legal method was used while presenting the establishment of institutional conditions of the environment of maritime economy. In turn, thanks to the comparative method it was presented to what extent the assumptions of the governmental program concerning the development of the shipbuilding industry were realized in the years 2016-2018. Basing on the conducted research it should be stated that the establishing of a powerful center for the construction of big ships within the premises of the former Szczecin shipyard may constitute a difficult task due to insufficient experience of MSR Gryfia in the construction of such specialized vessels as passenger and freight ferries. Another issue consists in the shortage of qualified staff, damaged infrastructure of former Szczecin shipyard which requires additional funds, not specified source of funding of the "Batory" program as well as the crisis in global shipbuilding industry from the year 2016, strictly connected with reduced number of orders.
\end{abstract}

Key words: policy of the government, political decisions, maritime economy, shipbuilding industry, European Union

\section{Introduction}

$\mathbf{S}^{\mathrm{s}}$ hipbuilding industry was and still is one of the most important branches of economy in Poland. Shipyards involved in the construction of ships constitute one of the branches of shipbuilding industry. Transition from centrally planned economy to market economy in Poland in the late 1980 s of the $20^{\text {th }}$ century resulted in difficult financial situation of Polish manufacturing shipyards. For this reason, the policy of Polish government was directed towards increasing the effectiveness of the functioning and competitiveness of shipyards as well as towards adapting their activity to the principles of 
market economy. In spite of the restructuring of Polish shipyards, desired effects were not achieved. At the beginning of the year 2000, their activity was generating losses. It was difficult for the shipyards to ensure the continuity of production as well as pay their liabilities on time. In 2007, Polish government sold the majority of shares of the Gdańsk Shipyard SA to the company ISD Polska Sp. z o.o., belonging to a Ukrainian owner from Donbass. In this way, the Ukrainian investor became the owner of $83 \%$ of shares of Gdańsk Shipyard SA. Privatization and restructuring of Gdańsk Shipyard S.A. did not result in the improvement of its financial situation. In the years 2013-2015, as a result of employment reduction, over a thousand employees lost their jobs in the shipyard. In July 2018, governmental Industrial Development Agency SA repurchased from the Ukrainian investor the shares of Gdańsk Shipyard S.A. Thanks to the shares of the shipyard being taken over by the State Treasury, its bankruptcy was avoided (Baca-Pogorzelska, Potocki, 2018, p. A 10).

The situation of Szczecin and Gdynia shipyards looked differently as they were not privatized due to the lack of investors interested in purchasing their shares. Direct reason for the collapse of the Szczecin Shipyard Nowa Sp. z o.o. (SSN) and Gdynia Shipyard SA (SG SA) was constituted by the decision of European Commission (EC) as of 2008, which stated that public assistance provided to the shipyard was against the law of the European Union (EU). According to the commission, shipyards in Szczecin and Gdynia did not achieve profit from the manufactured ships and their activity was possible thanks to state support (Informacja, 2011, p. 19). In accordance with the commission's decision, the property of Gdynia and Szczecin shipyards was divided and sold. Funds acquired in this way were used for paying up their creditors. Private shipyards and companies manufacturing ship equipment were established in place of the collapsed state enterprises. After the year 2010, Polish shipyard industry began to develop. Many different companies organized and managed following the example of Western European states were established.

The aim of the article is to present the assumptions and implementation of the program of the Prawo i Sprawiedliwość (PiS; Law and Justice) political party in the field of the development of shipbuilding industry in Poland after 2015 in the context of the situation on the shipyard market in Poland and in the world. What is more, the activities of Polish government in view of the activation of manufacturing shipyards are going to be discussed.

While analyzing the influence of the decisions of Polish government on the development of shipbuilding industry in Poland in 2015, the attempt was undertaken to answer the following problematic questions:

1. What are the assumptions of the policy of Polish government in the field of the development of shipbuilding industry in Poland after 2015 taking into consideration the situation on the shipyard market in the world?

2. What is the scope of realization of Polish government's program assumptions with relation to the shipbuilding industry in the years 2016-2018?

3. Is the current policy of the government going to influence the creation of a powerful shipbuilding center within the former Szczecin shipyard?

Aiming at obtaining the answer to the questions asked in this way, the decision method, together with institutional and legal as well as statistical and comparative method were applied. The conducted studies concern the years 2015-2018. 
Research material used in the article included among others: documents of Polish government and parliament, reports by Clarksons Research, Shipyards' \& Maritime Equipment Association (Sea Europe) as well as by Supreme Audit Office (NIK), maritime economy statistical yearbooks as well as articles and interviews published in trade magazines ("Nowy Przemyst," "Obserwator Morski," "Polska na Morzu") and national press (“Dziennik. Gazeta Prawna," "Nasz Dziennik," "Rzeczpospolita”).

\section{Situation on the shipbuilding market in Poland and in the world}

Shipbuilding market is strictly connected with current and forecast situation of world's economy. The development of international maritime trade is to a large extent determined by the condition of world's economy and trade as well as the price of petroleum, rapid expansion of electronics (e-commerce) as well as the situation in the sector of cargo ship transport. Since 2011, the abovementioned factors have influenced the prices of freight rates, which remained "definitely below the average from the last 25 years, while in the year 2016, they reached the historical minimum" (Polski, 2018, p. 9). Low freight rates together with the lack of possibility to take up bank loans for the financing of shipbuilding constituted direct cause for resigning from the purchase of new vessels by freighters.

In the years 2005-2008 the number of shipyards all over the world which signed the contract for the construction of at least one ship remained at the level of $87 \%$ of the total number of active shipyards. Since 2010, orders and ship manufacturing in the world decreased in comparison to the previous period. This trend persisted in the following years. According to the report of Clarksons Research consulting and analytical company, in the years 2010-2015 the number of contracts signed by the shipyards for the construction of at least one ship amounted to $49 \%$ of the total number of active shipyards in the world (Leadership, 2013, p. 4, 5; Starańczak). In 2015, the decrease in orders by $40 \%$ in comparison to the previous year took place in connection to ships manufactured in Asian shipyards. The demand for Chinese bulk carriers and offshore vessels went down. Korean shipyards (among others Hyundai Heavy Industries, Daewoo Shipbuilding, Samsung Heavy Industries) recorded the loss from their activity. In the first half of the year 2016, these shipyards dismissed 20 thousand employees (Sea, 2016, p. 5-7; Stocznie, 2016 , p. 39). In 2016, contracts for the construction of at least one ship were signed by 48 Chinese shipyards (including 26 shipyards supported by the state). To compare: in 2007 , orders for the construction of at least one ship were received by 284 shipyards. In 2016 in Japan, orders were made for the construction of ships in 22 shipyards, and in 2015 - in 60 shipyards. In South Korea 11 shipyards signed contracts for the construction of at least one ship in 2016 (Tegoroczny).

In the years 2016-2017, world's shipbuilding industry experienced the crisis, which was connected with the decrease in the number of orders and in the manufacturing of ships. In 2016, 2474 ships were constructed in the shipyards all over the world, while in 2017 - 2351 (Sea, 2017, p. 3-7). In 2016, orders for the construction of new ships in the shipyards of South Korea were $84.2 \%$ lower in comparison to the year 2015. The portfolio of orders made by Chinese shipyards in 2016 decreased by $58.5 \%$ in comparison to 
the year 2015. Limited number of orders for new vessels made by the freighters resulted in private and state shipyards going bankrupt in China (among others Mingde Heavy Industries, Wuzhou Shipyard, Sainty Marine) (Grzybowski).

In 2017, world's portfolio of shipbuilding orders amounted to 82.8 million CGT ${ }^{1}$ and was estimated at the amount of USD 236.5 billion. The portfolio for the orders of ships from the year 2017 constituted about $40 \%$ of the portfolio of orders for the construction of ships from 2008 (Sea, 2018, p. 1). Taking into account the orders for the construction of ships in 2017 (20.2 million CGT), their increase in comparison to the previous year should be noticed (10.6 million CGT). In 2017, world's ship manufacturing market experienced the growth in the orders for tankers and bulk carriers. Within the period of crisis on the shipbuilding market, Korean Hyundai Heavy Industries (HHI) shipyard contracted in 201762 ships with the value of USD 3.8 billion. Two thirds of the ships ordered were tankers with the load capacity exceeding 100 thousand DWT.

The decrease in the number of orders for new ships in the first decade of the $21^{\text {st }}$ century resulted in the liquidation of many shipyards. In 2008, there were 934 shipyards in the world, while in 2017 - 358. From the beginning of the present century, world's manufacturing of ships was in more than $80 \%$ realized by Asian shipyards, which offered the cheapest ships in the world. In 2016, the share of Asian shipyards in the world's portfolio of orders amounted to $86.9 \%$, while at the end of September 2017 it decreased to $83.9 \%$. In 2017, the biggest number of contracts for the construction of ships was signed by the shipyards from China and Japan. In the years 2016-2017, shipyards in the Far East were realizing in particular the orders for the manufacturing of bulk carriers, container ships and gas carriers. In 2017, shipbuilding industry in China occupied the first position in the world in the category of new orders as well as finished ship construction projects.

European shipyards, including Polish ones, in order to maintain their position on the shipbuilding market dominated by Asian shipyards, benefited from the niche by offering touristic ships, maritime auxiliary ships supporting maritime oil and and natural gas industry, ro-ro ships and ferries. European shipbuilding industry also specializes in the manufacturing of structures for wind power industry.

In 2016, the share of European shipyards in the world's portfolio of orders amounted to $10.9 \%$. At the end of September 2017 it increased to $14.8 \%$. Italy and Germany had the most extensive portfolio in Europe. In 2016, European shipyards signed contracts for the construction of 155 ships, while in $2017-180$ ships. It is worth noticing that European shipyards specialized in the construction of complex and high-cost vessels (e.g. touristic ferries, fishing cutters as well as scientific and research ships), demanding extensive workload and highest quality technology. Thanks to this, shipyards in Europe had the biggest portfolio of ship orders from the value-related perspective in the world. In 2017, it amounted to USD 64 billion. At the same time, the portfolio of ship orders from the value-related perspective in China amounted to USD 62.9 billion, in South Korea - USD 52.2 billion, Japan - USD 30.4 billion (Sea, 2018, p. 7). Table 1 presents portfolio size for the orders, new orders as well as the manufacturing of ships in chosen countries in the world in the years 2007-2017.

\footnotetext{
${ }^{1}$ CGT - compensated gross tonnage making it possible to assess shipyard's capacity.
} 
Size of the portfolio of orders, new orders as well as the production of ships in the world and in chosen countries in the years 2007-2017

\begin{tabular}{|c|c|c|c|c|c|c|c|c|c|c|c|c|}
\hline \multirow{2}{*}{ Country } & \multirow{2}{*}{$\begin{array}{c}\text { Activity } \\
\text { of shipyards }\end{array}$} & \multicolumn{11}{|c|}{ Years } \\
\hline & & 2007 & 2008 & 2009 & 2010 & 2011 & 2012 & 2013 & 2014 & 2015 & 2016 & 2017 \\
\hline \multirow[t]{3}{*}{ World* } & production & 2227 & 3162 & 3477 & 3706 & 3605 & 3655 & 3061 & 2950 & 2770 & 2474 & 2351 \\
\hline & new orders & 4404 & 2928 & 1599 & 2523 & 1940 & 1977 & 3375 & 2744 & 2273 & 798 & 1169 \\
\hline & order portfolio & 10703 & 11729 & 9632 & 8308 & 7345 & 5892 & 5994 & 6148 & 6149 & 5065 & 4734 \\
\hline \multirow[t]{3}{*}{ China } & production & 459 & 836 & 1078 & 1402 & 1405 & 1441 & 1060 & 911 & 923 & 791 & 769 \\
\hline & new orders & 1538 & 951 & 605 & 928 & 554 & 651 & 1343 & 1130 & 742 & 215 & 362 \\
\hline & order portfoli & 3203 & 4004 & 3524 & 2968 & 2483 & 1927 & 2161 & 2454 & 2354 & 1893 & 1742 \\
\hline \multirow{3}{*}{$\begin{array}{l}\text { South } \\
\text { Korea }\end{array}$} & production & 434 & 518 & 523 & 524 & 571 & 471 & 387 & 343 & 356 & 360 & 293 \\
\hline & new orders & 1191 & 557 & 140 & 464 & 351 & 231 & 557 & 338 & 276 & 73 & 159 \\
\hline & order portfolio & 2259 & 2303 & 1675 & 1357 & 1078 & 764 & 890 & 865 & 774 & 514 & 422 \\
\hline \multirow{3}{*}{ Japan } & production & 559 & 510 & 281 & 385 & 327 & 361 & 566 & 600 & 484 & 152 & 172 \\
\hline & new orders & 518 & 560 & 575 & 577 & 592 & 587 & 540 & 522 & 506 & 506 & 485 \\
\hline & order portfolio & 1491 & 1607 & 1286 & 1105 & 933 & 740 & 825 & 941 & 1020 & 915 & 772 \\
\hline \multirow{3}{*}{$\begin{array}{l}\text { European } \\
\text { Union and } \\
\text { Norway }\end{array}$} & production & 393 & 414 & 367 & 332 & 244 & 260 & 258 & 292 & 201 & 192 & 226 \\
\hline & new orders & 422 & 235 & 108 & 197 & 204 & 191 & 230 & 217 & 241 & 155 & 180 \\
\hline & order portfolio & 1340 & 1081 & 749 & 540 & 523 & 466 & 466 & 436 & 515 & 429 & 493 \\
\hline
\end{tabular}

* All countries in the world where the ships are manufactured were taken into account (among others the United States, Argentina, Brazil).

Source: Own study basing on: Sea, 2014, s. 20; Sea, 2018, p. 16-20.

Until the year 2009, manufacturing shipyards in Szczecin and Gdynia were realizing contracts among others for the construction of container ships, general cargo ships and ferries. When the shipyard in Szczecin was closed, entities involved in the manufacturing of small vessels and steel structures as well as in equipping ships and hulls and cooperating with the off shore sector began their activity within its premises.

From the year 2010, the following companies conduct their activity within the premises of the former SG SA: Shipyard Crist Sp. z o.o., Renovation Shipyard Nauta SA (SR Nauta SA), Energoinstallation Energomontaż Północ SA, Gafako Sp. z o.o. as well as Pomeranian Special Economic Zone Pomorska Specjalna Strefa Ekonomiczna Sp. z o.o. (PSSE). ${ }^{2}$ Shipyard Crist Sp. z o.o. specializes among others in the construction of specialist ships, ship elements including equipped hulls, steel structures as well as offshore objects (Profil). In 2017, about 1500 staff members and cooperators were employed in the Shipyard Crist Sp. z o.o. The activity of the shipyard was profitable in spite of its liabilities connected with the loans taken for the implementation of the investment program (Polski, 2018, s. 29). Both SR Nauta SA as well as Energomontaż Północ Gdynia SA, Gafako Sp. z o.o. are state-owned companies involved in constructing steel structures for the off shore sector. In addition, SR Nauta SA offers ship repair and manufacturing services. At the beginning of the year 2018, about 500 staff members were employed in the shipyard. SR Nauta SA finished the year 2016 with the loss of over PLN 13 mil-

2 Thanks to PSSE, the revitalization of Gdynia post-shipyard areas was performed; the highest building of former Gdynia shipyard was among others modernized, together with the infrastructure and roads; Baltic New Technologies Port was established. In the years 2011-2013, PSSE invested over PLN 100 million in the premises of former SG SA (Pomorska). 
lion net. The company experienced financial problems among others due to lost tenders for the construction of tugboats for the army as well as of the reconstruction of the Petrobaltic extractive platform. In 2018, SR Nauta SA in order to pay off its financial liabilities towards subcontractors and suppliers began selling the property of the shipyard. (Wojciechowski, 2018, p. 10).

In the Pomerania region, apart from the abovementioned companies representing the shipbuilding industry, Gdańsk Józef Piłsudski’s "Remontowa" (Renovation) Shipyard SA (GS "Remontowa" SA) ${ }^{3}$ deserves particular attention, together with Remontowa Shipbuilding SA (from the year 2011 - Stocznia Północna (Northern Shipyard) SA). Both shipyards are private entities. GS "Remontowa" SA is involved in the repair and reconstruction of among others bulk carriers, specialist ships, passenger ships, gas carriers as well as oil platforms. In 2017, shipyard staff consisted of about 2400 employees. In the same year, the shipyard obtained additional capital in view of the threat of losing its financial liquidity (Bade, Ludwig, 2016, p. 10; Polski, 2018, p. 27).

The activity of Remontowa Shipbuilding SA, in turn, was and is concentrated on the construction of small and medium-sized ships (among others passenger ferries, ships for the off shore sector) as well as steel structures. At the end of the year 2017, Remontowa Shipbuilding SA experienced financial problems. Danish and Norwegian freighters resigned from purchasing ships which they had ordered. The cause of premature termination of contracts by freighters was the unfavorable situation on the off shore market (Fudowicz, Łapiński, Peterlik, Wyżnikiewicz, 2007, p. 9-11; Kasińska, 2016, p. 5, 6).

Within the premises of the former SSN (in the years 2013-2017 Szczecin Industrial Park Szczeciński Park Przemysłowy Sp. z o.o. (SPP ${ }^{4}$ ), and from January 2018 Szczecin Shipyard), the repair, modernization, construction of ships and steel structures for the off shore sector is performed by over 50 companies from the shipbuilding sector, employing nearly 2 thousand people. In 2017 in Szczecin (not only within the premises of the former shipyard) and Świnoujście several dozen private companies were functioning - PTS Sp. z o. o, Hullkon Marina Faktory, Finomar Sp. z o.o., Poltramp Yard SA. Their activity was and is connected with the construction of hulls, additional structures as well as the reconstruction of ships. So far, there is no big shipyard in Szczecin, which would play the leading role in the manufacturing of ships and with which the existing private companies would cooperate. It is necessary to emphasize that the activity of the majority of private companies connected with the shipbuilding industry used to bring and still brings a lot of profits. In October 2015, the Head of Ship Forum Employers' Association as well as Remontowa Shipbuilding SA Andrzej Wojtkiewicz, relating to the situation of private shipyards in Poland, concluded that it is very favorable. The offer of shipyards "begins with steel structures used for extraction installations on the sea up to fully equipped

${ }^{3}$ Gdańsk Shipyard "Remontowa" is the mother company of Remontowa Holding SA Capital Group consisting also among others of Remontowa Shipbuilding SA and smaller companies building partial ship equipment. Remontowa Holding is one of the biggest shipbuilding complexes in Europe. In 2015, the entire holding concentrated 20 companies, which employed over 9 thousand staff members. In the same year, the revenues of the holding exceeded PLN 3 billion per year (Lentowicz, 2015, p. B 7; Stocznia).

${ }^{4}$ In 2010, the majority of the assets of the collapsed SNN was purchased by financial association Towarzystwo Finansowe Silesia Sp. z o.o. (TF Silesia Sp. z o.o.). Three years later, SPP was established on within the former SSN premises. 
ships representing very high value, realizing complicated tasks on the North Sea or other waters all over the world. [...] The Asian market offers cheap constructions, as price prevails there over quality. These ships are not as technically advanced as the ships constructed in Europe" (Polskie prywatne). While analyzing the activity of private Polish shipyards it is necessary to consider the fact that since 2010, companies representing the shipbuilding sector have been constructing technologically advanced ships.

Apart from private shipyards in Szczecin, Maritime Repair Shipyard Gryfia SA(MSR Gryfia SA) conducts its activity and it is owned by the State Treasury. The scope of its services includes repair, reconstruction and construction of small vessels as well as performs off shore structures. In spite of the fact that Gryfia SA was subject to restructuring, it still experiences difficulties in maintaining financial liquidity and profitability. In 2015, losses from the activity of MSR Gryfia SA amounted to over PLN 17 million. In 2016, the government announced that the shipyard lost its financial liquidity. In 2017, about 500 staff members were employed in MSR Gryfia SA (Milionowe).

Private shipyards established in place of the liquidated SSN turned out to be competitive on the world market, manufacturing technologically advanced ships. According to the data by the Center of Ship Technology, in 20165.2 thousand entities directly connected with the shipbuilding industry conducted their activity, together with 12 thousand companies cooperating with them. About 90 thousand people were employed in the shipbuilding sector (Polskie stocznie). In the years 2012-2017, the portfolio of orders of Polish shipyards included fishing ships, ferries, river ice-breakers, off-shore vessels. In Poland, shipyards specialized mainly in constructing and equipping hulls, vessels with LNG propulsion as well as yachts. In the years 2007-2017, 178 ships were constructed, which was presented in Table 2.

Table 2

Production of ships in Poland in the years 2007-2017

\begin{tabular}{|l|c|c|c|c|c|c|c|c|c|c|c|}
\hline Years & $\mathbf{2 0 0 7}$ & $\mathbf{2 0 0 8}$ & $\mathbf{2 0 0 9}$ & $\mathbf{2 0 1 0}$ & $\mathbf{2 0 1 1}$ & $\mathbf{2 0 1 2}$ & $\mathbf{2 0 1 3}$ & $\mathbf{2 0 1 4}$ & $\mathbf{2 0 1 5}$ & $\mathbf{2 0 1 6}$ & $\mathbf{2 0 1 7}$ \\
\hline Number of ships & 30 & 20 & 25 & 24 & 14 & 15 & 12 & 8 & 7 & 12 & 11 \\
\hline
\end{tabular}

Source: Own study basing on: Rocznik, 2011, s. 277; Rocznik, 2013, s. 267; Rocznik, 2017, p. 257.

In the years 2016-2017, shipyards in Poland were more frequently realizing the contracts for the construction and equipment of hulls than for the manufacturing of fully equipped vessels. In 2016, Polish shipyards constructed 37 hulls (i.e. two times more than when it comes to fully equipped ships), while in $2017-45$. Foreign shipyards (German, Norwegian and Dutch) benefited from the offer of shipyards situated in Poland. Total value of revenues obtained by companies representing the shipbuilding market in Poland amounted to PLN 10.6 billion for the year 2016.

\section{Shipbuilding industry in program assumptions of the government}

2015 was in Poland the year when elections were held. Presidential elections took place in May, while parliamentary elections in October. During the campaign Andrzej Duda, presidential candidate and Beata Szydło - candidate for the Prime Minister an- 
nounced the creation of modern shipbuilding industry. According to the presidential candidate, it was necessary to reconstruct the shipbuilding industry in Szczecin, involving the companies established after the collapse of SSN in building big modern ships. These activities were aimed at creating new workplaces and encouraging young Poles to work in the country and not look for it abroad. In May 2015, during his visit in Szczecin, A. Duda said that "it is possible to reconstruct Polish industry, that we are able to reconstruct our country, to modernize it, create workplaces for the young. The nation consisting of 38 million inhabitants living in the country with a long coast cannot accept the situation when the ships are built somewhere else" (Andrzej). B. Szydło also opted for the development of shipbuilding industry and maritime navigation. It is here worth to remind that election postulate concerning the future of shipbuilding industry presented by the candidates for president and prime minister was in line with program assumptions of PiS.

In May 2015, Andrzej Duda was elected president of the Republic of Poland. In October, PiS won parliamentary elections. Voting result made it possible, for the first time since 1989 , for only one party to form the government without entering into coalition with any other political formation.

In November 2015, President A. Duda appointed B. Szydło to the position of Prime Minister and the members of her government were sworn. In her parliamentary exposé, B. Szydło announced the reestablishment of the ministry of maritime economy, liquidated in 2007. ${ }^{5}$ Its task was supposed to be in particular the restoration of shipbuilding industry and inland navigation (Sprawozdania, 2015, p. 56).

According to B. Szydło's announcement, the Ministry of Maritime Economy and Inland Navigation (MGMiŻŚ) was formed, with Minister Marek Gróbarczyk ${ }^{6}$ as its head. He was supposed to be responsible for maritime shipping and administration (maritime offices) and maritime economy. Minister's task also included proprietary supervision of the ports, freighters, fishing and maritime education as well as managing the negotiations connected with acquiring EU funds for the development of maritime economy, fishing and inland navigation (Rozporządzenie, 2015; Rozporządzenie, 2018). The establishment of MGMIŻŚ created institutional conditions for the development of maritime economy, including the revitalization of shipbuilding industry, which constitutes the responsibility of one ministry. The task of the ministry of maritime economy and inland navigation was to prepare the draft of the act making it possible to reconstruct shipbuilding industry. Thanks to new legal provisions, entities active within shipyard premises in Szczecin and Gdynia were supposed to have the possibility to build ships benefiting from tax exemptions. Minister M. Gróbarczyk, relating to the situation of the shipbuilding industry in Poland stated that there exists the demand for the construction of ships for inland navigation and navy as well as for foreign freighters. Government's

${ }^{5}$ The Ministry of Maritime Economy was liquidated when Donald Tusk was the Prime Minister. In the years 2007-2015 subsequent sectors of maritime economy were subjected to different ministries, among others the Ministry of Infrastructure, the Ministry of Transport, Construction and Maritime Economy as well as the Ministry of State Treasury.

${ }^{6}$ In the years 2006-2007 M. Gróbarczyk was responsible for maritime economy in Jarosław Kaczyński’s environment. Since December 2017 - the Head of MGMiŻŚ in Primer Minister Mateusz Morawiecki's government. 
aim was to establish conditions which will make it profitable to build ships on the greater scale than it has been so far within holdings or shipbuilding groups (Stefaniak, Ziarno, 2016, p.16).

The development of shipbuilding industry constituted an important element of the Plan for responsible development developed by Mateusz Morawiecki, deputy Prime Minister and Minister of Development. In February 2016, the plan was approved by the government (Uchwała, 2016). According to its assumptions, shipbuilding industry was supposed to become the flywheel of Polish economy. The realization of the plan was coordinated on behalf of Prime Minister B. Szydło by deputy Prime Minister and Minister of Development Mateusz Morawiecki. In order to make the implementation of the tasks included in the Plan for responsible development more effective, working teams were appointed by the deputy Prime Minister. As a result of the works conducted by the Ministry of Development and with the use of materials prepared by subsequent ministries and expert environments, Strategy for Responsible Development until 2020 (with the perspective until 2030) (SOR) was established, commonly called Morawiecki's plan. In February 2017, the government approved the strategy (Uchwała, 2017). The consolidation as well as establishing favorable conditions for the development of shipbuilding industry constituted the objective of the strategy.

Ensuring legal, organizational and financial frameworks was supposed to result in the stimulation of shipbuilding industry to activity, development of scientific centers working on innovative ship types as well as increasing the competitiveness of Polish shipyards on the international market. "Batory" program constituted part of Morawiecki's plan, including the prospects for the construction of passenger ferries for Polish freighters as well as platforms for the exploitation of maritime resources (Strategia, 2017, p. 78).

\section{Assumptions of the act on the motivation of shipbuilding industry and complementary production to activity}

From December 2015 until February 2016, works on the draft of the act on the motivation of shipbuilding industry and complementary production to activity (commonly called draft shipbuilding act) were in progress at MGMiŻŚ. In March 2016, within the premises of the liquidated Szczecin shipyard, presentation of draft shipbuilding act took place, with the participation among others of the minister of maritime economy and inland navigation M. Gróbarczyk, his deputy Minister Paweł Brzezicki as well as the Minister of Finance Paweł Szałamacha. The participation of the Minister of Finance in the presentation of the assumptions of the shipbuilding act suggested that the solutions presented in the draft act received the approval of the ministry of finance. Draft shipbuilding act included the solutions concerning the area of taxes, special economic zones as well as the access to EU funds. Tax proposals were addressed to companies involved in the construction or reconstruction of ships. Draft act included the exemptions relating to VAT from the purchased materials and equipment used by the companies for the construction or reconstruction of ships. It is worth noticing here that up to that time, only the ships ready for sale were subject to VAT exemptions. Jerzy Czuczman, representative of Forum Okrętowe Association of Polish Maritime Industries, expressed his positive 
opinion concerning the solutions ensuring VAT exemptions for companies. According to him, the subject of VAT was "of particular importance, as on the national scale it gives several dozen million zlotys, which may be used by the companies for their purposes, e.g. research and development" (Branża).

Draft shipbuilding act included also the possibility for the enterprises to choose taxation method. The companies had the possibility to pay CIT or new flat-rate tax amounting to $1 \%$ of the value of manufactured products sold (but only when the value of the realized contract exceeded 5 million euros). Proposals of changes in tax regulations included in the draft act were in line with the law of the European Union (Losz, 2016, p. 1, 8). According to the ministry's draft act, companies manufacturing ships will have the right to apply for including the territory where they conduct their activity to Special Economic Zones (SSE). As far as financial support is concerned, it was decided to launch loan procedure. The support was supposed to be provided by state-controlled banks. Nonrepayable financial support within so called national intelligent specializations was another form of support. The fact of the shipbuilding act entering into force was supposed to result, during 10 years of its validity, in the creation of about 5 thousand workplaces in the shipbuilding industry (Kuźmiuk, 2016). Government's tax solutions were supposed to increase the effectiveness of realization of contracts for the construction of ships and motivate the activation of shipbuilding industry in Western Pomeranian voivodeship.

At the beginning of April 2016, draft shipbuilding act was approved by the government and at the end of May 2016, it was received by the Polish Sejm (Sejm RP, 2016 p. 1), where parliamentary opposition expressed their criticism. Both deputies from PO (Platforma Obywatelska, Civic Platform) political party (Tadeusz Aziewicz, Arkadiusz Marchewka, Włodzimierz Nykiel) as well as Nowoczesna political party (Piotr Misiło) presented their reservations concerning among others the title of the draft act, claiming that it should be changed into: draft act on the lump-sum tax from the value of the manufactured goods sold. According to the deputies, the document did not specify any forms of motivating the shipbuilding industry to activity, apart from introducing lump-sum tax for this type of undertakings. For this reason, parliamentary opposition claimed that the subject of the draft act consisted in tax changes. Paweł Brzezicki, Deputy Minister from MGMiŻŚS stated that the suggestion for changing the name of the shipbuilding act was not justified. P. Brzezicki "advised the opponents not to confuse the activity of renovation shipyards with that conducted by the shipyards manufacturing new ships" (Sejm. Projekt). Members of Parliament from PO and Nowoczesna political parties suggested that tax reliefs should be attributed not only to companies involved in the construction of ships, but also in their repair. What is more, it was suggested to resign from the limit of 5 million euros for the realization of the contract for the reconstruction of ships in order to benefit from lump-sum tax amounting to $1 \%$ of the value of manufactured goods sold. With the limit of 5 million euros maintained, only big companies whose contracts for shipbuilding services amounted to PLN 20 million at one time could benefit from lump-sum tax in the amount of $1 \%$ of the value of the offer sold (Sprawozdania, 2016, p. 80-84).

Amendments to draft shipbuilding act submitted by deputies representing PO and Nowoczesna political parties were rejected by the Sejm of the Republic of Poland. Deputies representing Kukiz'15 and PSL Polish People's Party supported government's draft 
shipyard act stating that it may have a positive influence of the development of shipbuilding industry. The Parliament approved government's draft shipbuilding act. On July $30^{\text {th }} 2016$, the act was signed by President Andrzej Duda. It came into force on January $1^{\text {st }} 2017$.

It is necessary to emphasize that the European Commission, while expressing their opinion on the shipbuilding act approved by the Polish Parliament stated that they "do not question the right of Poland to decide on their own tax system. However, according to the Treaty on European Union, the Commission has to verify whether the tax system remains in accordance with EU principles of state support and whether it grants selective benefits to some industries over the other" (Pomoc, 2018). By the end of September 2018 , the Commission has not made any decision with reference to the taxation system for shipyards and companies cooperating with them in Poland yet.

\section{Realization of the "Batory" program}

Adoption of the shipbuilding act by the Parliament constituted the first stage of realization of the assumptions of governmental policy concerning the development of the shipbuilding sector. Next stage consisted in the consolidation of shipbuilding industry as well as the construction of passenger and car ferries for a Polish freighter - Polish Baltic Shipping PŻB SA, which were supposed to be constructed in Polish repair shipyards. Tightening the cooperation between Polish shipyards and Polish freighters within the scope of construction and classification of ships constituted main objective of the "Batory" program.

In January 2017, in order to consolidate Polish shipbuilding industry, Mars Investment Fund (FI Mars) ${ }^{7}$ purchased at the price of PLN 100 million from TF Silesia Sp. z o.o. $100 \%$ of shares in SPP. Thanks to including SPP in FI Mars, one of the biggest shipbuilding groups by the Baltic was established, supervised by the Ministry of National Defense (MON) by the intermediary of PGZ SA. The shipbuilding group was formed among others by MSR Gryfia SA and SR Nauta SA. By including SPP in the shipbuilding group managed by PGZ SA, the Szczecin facility was given the opportunity to take part in the realization of the project of modernization of Polish fleet (Szczecin).

In March 2017, PŻB SA signed in Kołobrzeg the contract for the construction of passenger and freight ferry with MSR Gryfia SA. It is necessary to emphasize that both PŻB SA as well as MSR Gryfia SA are state companies. MSR Gryfia SA specializes in the repair of ships and does not have the experience in the construction of such specialized vessels as the passenger and freight ferry. For several years, its activity has recorded losses. Financial condition of PŻB SA is much better. In 2015, the activity of this freighter from Kołobrzeg brought the profit amounting to PLN 33.1 million, and in 2016 - PLN 38.2 million (Stareńczak, 2018, p. 20-23; Stankiewicz, 2017, p. 4).

According to the contract, Szczecin repair shipyard became responsible for the performance of the entire investment project, from design works to the manufacturing of the vessel. New vessel was supposed to operate ferry connections between Świnoujście and Ystad, including 70 staff members and 400 passengers. It should be stated that initially,

\footnotetext{
${ }^{7}$ Managed by Polish armament group Polska Grupa Zbrojeniowa SA (PGZ SA).
} 
Polish government planned to extend the fleet of the freighter from Kołobrzeg by purchasing two ferries which were supposed to be bigger than the ferry which MSR Gryfia planned to construct for PŻB SA. It is worth noticing that the Council of Ministers has not expressed their official statement in connection with this change of plans.

On June 23 $3^{\text {rd }}$ 2017, on the Wulkan slipway in Szczecin, the keel (first element of the hull) for the construction of passenger and car ferry for PŻB SA was installed. Representatives of the government and parliament as well as the CEOs of PŻB SA and MSR Gryfia SA and FI Mars took part in the ceremony (Stefaniak, 2018, p. 12, 13). It should be noticed that politicians representing the governing formation together with public media publicized the act of installing the keel, treating it as a symbol of revitalization of the shipbuilding industry in Szczecin. Constructing the ferry for the freighter from Kołobrzeg was begun without the design for the vessel. In August 2018, it still has not been prepared. What is more, in order to implement the design, funding for the reconstruction of shipbuilding infrastructure taken over by SPP is necessary. According to A. Srzeboński, CEO of SPP SA, investment needs amount to PLN 93 million. So far, SPP has spent PLN 10 million from their own funds, among others for the renovation of the Wulkan slipway. In June 2017, the minister of maritime economy and inland navigation M. Gróbarczyk ensured that "the financing of the construction of ferries is 'buttoned up' and there are also funds for more equipment for the shipyard in Szczecin" (Gróbarczyk, 2017). The minister did not specify the source of funding of the construction of the vessel. According to the estimations by MGMiŻŚ, construction costs for one ferry should amount to EUR 100 million. According to the schedule of construction of the passenger and freight ferry, its launch is planned for the year 2019. Next year, PŻM is supposed to receive the ferry.

In July 2018, Polish government decided that Gdańsk Shipyard SA is going to be included in the process of reconstruction of the shipbuilding industry within the "Batory" program. For this reason, activities aiming at stabilizing the financial situation as well as acquiring new contracts were undertaken. In August, the CEO of Stocznia Gdańsk SA Marcin Stojek announced that the company is interested in participating in the realization of "Mosty dla Regionów" (Bridges for the Regions) governmental program. Diversification of orders together with new contracts shall constitute for the shipyard the opportunity to break the deadlock.

\section{Summary}

In order to answer the first question it should be stated that during the presidential and parliamentary campaign in 2015, both the presidential candidate as well as PiS candidate for the office of Prime Minister promised to reconstruct Polish shipbuilding industry. The realization of governmental program by PiS concerning the development of shipbuilding industry takes place in the atmosphere of criticism directed at the government of Donald Tusk, when the shipyards in Gdynia and Szczecin were liquidated, together with many companies cooperating with them.

Declaration to reconstruct the shipbuilding industry made by the government was in fact only an election slogan, as this industry did exist. Private companies were established in place of the Szczecin shipyard liquidated in 2009, realizing shipbuilding con- 
tracts as subcontractors. The activity of the companies is concentrated on repairs and the construction of small vessels. What is missing in the Western Pomeranian voivodeship it is an entity serving the function of the "integrator" of private shipbuilding companies which would support them in connection with financial potential necessary for the conclusion of contracts for the construction of big vessels. The assets of Gdynia Shipyard SA were in turn sold in 2009 to the Shipyard Crist Sp. z o. o., Renovation Shipyard "Nauta" SA as well as shipbuilding and off-shore companies. It is worth noticing that the situation of the shipbuilding industry in the Western Pomeranian voivodeship was and still is different than in the Pomeranian voivodeship. Shipyards active in Tricity are involved among others in the manufacturing of modern and specialized vessels, which results in their high position on the European shipbuilding market. According to the PiS government, the construction of shipbuilding industry in Szczecin was supposed to involve the establishment of a center the task of which would consist in the consolidation of private companies within the premises of Szczeciński Park Przemysłowy SPP Sp. z o.o. (Szczecin Shipyard). The government, aiming at the development of a powerful center of ship manufacturing in Szczecin, developed the "Batory" program. Thanks to the program, maritime renovation shipyard MSR Gryfia SA became responsible for the construction of passenger and freight ferries for Polish Baltic Shipping (PŻB SA).

In order to provide the answer to the second question it should be stated that according to the assumptions of the PiS political party program, the Ministry of Maritime Economy and Inland Navigation (MGMiŻŚ) was formed. The fact of establishing the ministry promoted the creation of institutionally favorable conditions for the development of maritime economy. Within the framework of the governmental program of reconstruction of the shipbuilding industry, MGMiŻŚS developed draft shipbuilding act which was adopted by the Parliament. Tax solutions suggested in the act are aimed to the revitalization of shipbuilding industry in Szczecin. It is highly probable that the construction of the first ferry for PŻB SA is not going to be realized on time, if it will be realized at all. In spite of the fact that in June 2017, the keel constituting the basis for the hull of the vessel was laid, complete ship design still has not been developed. MGMiŻ́́ did not specify the source of funding for the construction of the ferry as well as for new shipbuilding infrastructure equipment within former SNN premises.

Within the process of reconstruction of the shipbuilding industry, Polish government took Gdańsk Shipyard SA over from the Ukrainian investor. The purchase of the shipyard is synonymous to the restructuring of the enterprise thanks to the introduction of new technologies and the organization of the manufacturing process. The government aims at restoring the profitability of Gdańsk Shipyard SA.

As far as the answer to the last question formulated at the beginning of the article is concerned, we state that the future of the shipbuilding industry in Poland will be connected with the construction of specialized vessels, hulls as well as the reconstruction and repair of ships. Also the activity of shipyards in Western European countries will be connected with the construction of specialized vessels, high-technology units and cruise ships. It results from the fact that the manufacturing of bulk carriers, container ships and gas carriers is dominated by the market from the Far East. It is worth noticing that the shipyards in Poland manufacture not only for the shipbuilding and offshore industry. The manufacturing of exclusive vessels - mega yachts - is developing at an increasing scale. 
From 2010 it is possible to notice that Polish private shipyards are competitive on the European market due to manufacturing increasingly complicated vessels. In turn, the activity of state-owned shipyards (among others MSR Gryfia SA, SR Nauta SA) brings losses. In this situation, the realization of governmental plan "Batory" may constitute the source of doubts as MSR Gryfia SA generates loss on its activity. What is more, the shipyard specializes in the repair of ships and not in the manufacturing of passenger and freight ferries. Damaged infrastructure within the premises of former shipyard in Szczecin requires additional funding. Another problem consists in the lack of qualified staff (e.g. welders, assembly workers) that the companies conducting their activity within former shipyard premises are facing. In such circumstances the establishing of a powerful center for the construction of big ships within former shipyard premises may turn out to be particularly difficult. Ensuring permanent orders for services at competitive prices may constitute a big problem for the Szczecin consortium. All the more so that in last years, the shipbuilding industry in the world has to face the crisis connected with reduced number of orders and the solvency of shipyards. Since 2016 it is possible to notice global slowdown in the shipbuilding industry, which influences Polish companies. In the years 2016-2018, order portfolio for specialized vessels decreased significantly in comparison to previous years.

\section{Bibliography}

Andrzej Duda w Szczecinie: Należy wymagać od prezydenta, żeby miat wizję, żeby wskazał dokąd ma zmierzać państwo polskie, 18.05.2015, http://wpolityce.pl/polityka/244861-andrzej-duda-wszczecinie-nalezy-wymagac-od-prezydenta-zeby-mial-wizje-zeby-wskazal-dokad-ma-zmierzac-panstwo-polskie, 13.05.2018.

Baca-Pogorzelska K., Potocki M. (2018), Repolonizacja Stoczni Gdańsk stała się faktem, „Dziennik. Gazeta Prawna”, 23.07.2018.

Bade H., Ludwig T. (2016), Development of Word Shipbuilding. Facts. Figures and a Project Proposal, Industrial Europe Sector Committee Shipbuilding, Brussels.

Branża stoczniowa pozytywnie o zwolnieniu z podatku VAT w ustawie stoczniowej, 08.06.2016, https:// www.polskieradio.pl/42/273/Artykul/1629222,Branza-stoczniowa-pozytywnie-o-zwolnieniuz-podatku-VAT-w-ustawie-stoczniowej, 12.08.2018.

Fudowicz J., Łapiński K., Peterlik M., Wyżnikiewicz B. (2007), Przemyst stoczniowy w województwie pomorskim, „Raport Sektorowy. Przemysł Stoczniowy” Gdańsk.

Gróbarczyk: Finansowanie budowy promów jest dopięte, 23.06.2017, http://radioszczecin.pl/ 7,355796,grobarczyk-finansowanie-budowy-promow-jest-dopiete, 20.08.2018.

Grzybowski M., Azjatyckie stocznie na pochylni. Brak zamówień i liczne bankructwa, 11.05.2017, http://www.pgt.pl/azjatyckie-stocznie-na-pochylni, 23.08.2018.

Informacja o wynikach kontroli zabezpieczenia interesu publicznego w zwiazku z realizacja ustawy kompensacyjnej wobec Stoczni Gdynia SA oraz Stoczni Szczecińskiej Nowa Sp. z o.o. (2011), Najwyższa Izba Kontroli, Departament Gospodarki, Skarbu Państwa i Prywatyzacji, Warszawa.

Kasińska J. (2016), Innowacje produktowe kluczowym czynnikiem sukcesu w budowaniu i umacnianiu konkurencyjności polskiego przemystu stoczniowego na świecie, „Transport. Logika. Porty”, no. 2 .

Kuźmiuk Z., Ustawa rządu PiS to dodatkowe 5 tysięcy miejsc pracy w przemyśle stoczniowym, 29.03.2016, https://wpolityce.pl/gospodarka/286712-ustawa-rzadu-pis-to-dodatkowe-5-tysiecy-miejsc-pracy-w-przemysle-stoczniowym, 12.08.2018. 
Leadership. The Sea. New Opportunities for the Future (2013), European Commission, Brussels. Lentowicz Z. (2015), Morski przemyst na fali, „Rzeczpospolita. Ekonomia i Rynek”, 9.03.2015.

Losz K. (2016), Rozruchy w dokach, „Nasz Dziennik”, 14.03.2016.

Polski sektor stoczniowy. Stan obecny, perspektywy, zagrożenia (2018), Fundacja Instytut Studiów Wschodnich, Warszawa.

Milionowe straty i zadlużenie Gryfii. Minister zdradzit liczby, 26.10.2016, https://www.portalmorski.pl/stocznie-statki/33368-milionowe-straty-i-zadluzenie-gryfii-minister-zdradzil-liczby, 15.09.2018.

Polskie prywatne stocznie w świetnej kondycji, 16.10.2015, https://www.forbes.pl/wiadomosci/polskieprywatne-stocznie-w-swietnej-kondycji/pf7yh60, 22.01.2017.

Polskie stocznie moga liczyć na wsparcie samorzadów, 15.02.2018, https://www.rp.pl/Pomorze-Zachodnie-/302149963-Polskie-stocznie-moga-liczyc-na-wsparcie-samorzadow.html, 12.08.2018.

Pomoc państwa: Komisja zatwierdza pomoc inwestycyjna dla MŚP w sektorze stoczniowym w Polsce. Wszczyna dochodzenie w sprawie zachęt podatkowych dla polskich stoczni, 15.01.2018, http:// europa.eu/rapid/press-release_IP-18-242_pl.htm, 13.05.2018.

Pomorska strefa zainwestowała w tereny b. stoczni Gdynia ok. $100 \mathrm{mln} z \mathrm{zl}, 13.10 .2013$, https://www. $\mathrm{pb} . \mathrm{pl} /$ pomorska-strefa-zainwestowala-w-tereny-b-stoczni-gdynia-ok-100-mln-zl-733138, 12.08.2018.

Profil produkcyjny Crist, http://www.crist.com.pl/profil-produkcyjny,10,pl.html, 12.08.2018.

Rocznik Statystyczny Gospodarki Morskiej (2011), Główny Urząd Statystyczny, Urząd Statystyczny w Szczecinie, Warszawa-Szczecin.

Rocznik Statystyczny Gospodarki Morskiej (2013), Główny Urząd Statystyczny, Urząd Statystyczny w Szczecinie, Warszawa-Szczecin.

Rocznik Statystyczny Gospodarki Morskiej (2017), Główny Urząd Statystyczny, Urząd Statystyczny w Szczecinie, Warszawa-Szczecin.

Rozporządzenie Prezesa Rady Ministrów z dnia 10 stycznia 2018 r. zmieniajace rozporządzenie w sprawie szczegółowego zakresu działania Ministra Gospodarki Morskiej i Żeglugi Śródlądowej, Dz. U. 2018, item. 100.

Rozporządzenie Prezesa Rady Ministrów z dnia 17 listopada 2015 r. w sprawie szczegółowego zakresu działania Ministra Gospodarki Morskiej i Żeglugi Śródlądowej, Dz. U. 2015, item. 1909.

Sea Europe Shipbuilding Market Monitoring Report (2014), no. 35.

Sea Europe Shipbuilding Market Monitoring Report (2017), no. 42.

Sea Europe Shipbuilding Market Monitoring Report Full Year 2015 (2016), no. 40.

Sea Europe Shipbuilding Market Monitoring Report Full Year 2017 (2018), no. 44.

Sejm RP z VIII k., d. nr 557 (2016): Projekt ustawy o aktywizacji przemystu okrętowego i przemystów komplementarnych, Warszawa, 31.05.2016.

Sejm. Projekt ustawy stoczniowej po raz drugi, 5.07.2016, https://www.gov.pl/gospodarkamorska/ sejm-projekt-ustawy-stoczniowej-po-raz-drugi, 12.08.2018.

Sprawozdania stenograficzne z VIII k. SRP (2015), 1 posiedzenie SRP z 18.11. 2015.

Sprawozdania stenograficzne z VIII k. SRP (2015), 22 posiedzenie SRP z 05.07.2016.

Stankiewicz M. (2017), Odbudowa czy propaganda, „Rzeczpospolita. Życie Regionów”, 19.05.2017.

Starańczak P. B., Coraz mniej stoczni na świecie, Polska buduje mało statków „,pod klucz”, 21.07.2017, https://www.portalmorski.pl/stocznie-statki/36382-coraz-mniej-stoczni-na-swiecie, 09.08.2018.

Starańczak P. B. (2018), Inwestycje na miarę możliwości, „Polska na Morzu”, no. 1.

Stefaniak P., Ziarno J. (2016), Na szerokie wody, „Nowy Przemysł”, no. 2.

Stefaniak P. (2018), Promem do przyszłości, „Nowy Przemysł”, no. 3. 
Stocznia „Remontowa” kończy 65 lat, 17.11.2017, https://biznes.trojmiasto.pl/Stocznia-Remontowaskonczyla-65-lat-n118582.html, 28.08.2018.

Stocznie produkcyjne w glębokiej recesji (2016) „Obserwator Morski”, no. 12.

Strategia na rzecz Odpowiedzialnego Rozwoju do roku 2020 (z perspektywa do 2030 r.) (2017), Warszawa.

Szczecin. Konsolidacja polskiego przemystu stoczniowego, 24.01.2018, https://www.gov.pl/gospodarkamorska/szczecin-konsolidacja-polskiego-przemyslu-stoczniowego, 20.08.2018.

Tegoroczny portfel zamówień największej stoczni świata sięga już 3,8 mld dolarów, 01.06.2017, http:// www.gospodarkamorska.pl/Stocznie,Offshore/tegoroczny-portfel-zamowien-najwiekszejstoczni-swiata-siega-juz-38-mld-dolarow.html, 08.08.2018.

Uchwała Nr 14/2016 Rady Ministrów z dnia 16 lutego 2016 r. w sprawie przyjęcia „Planu na rzecz odpowiedzialnego rozwoju, https://www.miir.gov.pl/media/16403/uchwala_plan_odp_ rozw_16022016.pdf, 12.08.2018.

Uchwała nr 8 Rady Ministrów z dnia 14 lutego 2017 r. w sprawie przyjęcia Strategii na rzecz Odpowiedzialnego Rozwoju do roku 2020 (z perspektywa do 2030 r.), Dz. Urz. 2017, item. 260.

Wojciechowski P. (2018), Państwowa stocznia w ruinie, „Gazeta Wyborcza”, 27.03.2018.

\section{Założenia i realizacja polityki rządu polskiego w zakresie rozwoju przemysłu stoczniowego w Polsce w kontekście sytuacji na rynku stoczniowym w świecie}

\section{Streszczenie}

W 2015 r. rząd polski zapowiedział odbudowę przemysłu stoczniowego, angażując między innymi firmy powstałe po upadku stoczni w Szczecinie w budowę nowoczesnych dużych statków. Celem artykułu jest przestawienie założeń i realizacji polityki rządu polskiego w zakresie rozwoju przemysłu stoczniowego w Polsce po 2015 roku. Szczególną uwagę zwrócono na decyzje rządu w celu realizacji programu rozwoju przemysłu stoczniowego w kontekście sytuacji rynku stoczniowego na świecie. Starano się odpowiedzieć na pytania: Jakie są założenia polityki rządu polskiego w zakresie rozwoju przemysłu stoczniowego w Polsce po 2015 r., biorąc pod uwagę sytuację rynku stoczniowego na świecie?; W jakim zakresie założenia programu rządu polskiego wobec przemysłu stoczniowego zostały zrealizowane w latach 2016-2018? Czy obecna polityka rządu wpłynie na powstanie silnego ośrodka budowy statków na terenie byłej stoczni szczecińskiej? Dążąc do uzyskania odpowiedzi na postawione pytania badawcze, wykorzystano metodę decyzyjną, analizując decyzje Rady Ministrów dotyczące wdrażania programu „Batory”. Metodę instytucjonalno-prawną zastosowano ukazując powstanie instytucjonalnych warunków do rozwoju gospodarki morskiej. Z kolei dzięki metodzie komparatystycznej przedstawiono w jakim zakresie założenia rządowego programu dotyczące rozwoju przemysłu stoczniowego zostały zrealizowane w latach 2016-2018. Na podstawie przeprowadzonych badań należy stwierdzić, że powstanie silnego ośrodka budowy dużych statków na terenach byłej stoczni szczecińskiej może okazać się trudne z braku doświadczeń MSR Gryfia w budowie tak specjalistycznych statków, jakimi są promy pasażersko-towarowe. Innym problemem jest brak wykwalifikowanej kadry, zdegradowana i wymagająca doinwestowania infrastruktura po byłej stoczni w Szczecinie, brak wskazania źródła finansowania programu „Batory” oraz trwający od 2016 r. kryzys branży stoczniowej na świecie związany z redukcją zamówień.

Słowa kluczowe: polityka rządu, decyzje polityczne, gospodarka morska, przemysł stoczniowy, Unia Europejska 